\title{
IMPROVED THE ABILITY TO WRITE EXPLANATION TEXT COMPLEX THROUGH STAD MODELS IN IT AL FATTAH DESA LAMA PRIVATE HIGH SCHOOL STUDENTS
}

\author{
Nazra Arif ${ }^{1+}{ }^{\prime}$ Universitas Muhammadiah Sumatra Utara \\ 'Email:Ajanazra@gmail.com
}

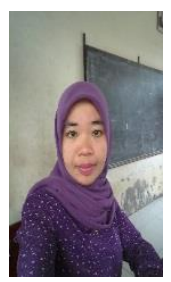

\begin{abstract}
Many activities are closely related to writing skills, for example making summaries, taking notes, writing minutes, writing various kinds of letters, writing activity plans, to the ability to write scientific papers. Writing complex explanatory text is writing that tells of an event that is arranged in an orderly manner. Meanwhile, the Student Teams Achievement Division (STAD) is a method that prioritizes good teamwork. The ability to write complex explanatory texts of class XI SMA SWASTA IT AL FATTAH Lma Village in cycle I was $(52 \%)$ complete learning and (48\%) students have not finished learning. Then after taking the action in cycle II, the learning outcomes are (95\%) complete and $(5 \%)$ have not finished learning
\end{abstract}

Keywords: ability, writing, complex explanatory text, STAD.

\section{INTRODUCTION}

In the teaching or learning process the teacher plays the role of both director and actor. This means that the teacher holds the duties and responsibilities of planning and implementing teaching in schools. Therefore, if students show less skills in a subject, it can be said that the teacher's lack of success in Teaching and Learning Activities (KBM).

One thing that can be used to improve the achievement of Indonesian subjects in writing complex explanatory texts developed by the teacher needs to pay attention to the quality of learning caused by several factors, namely: (1) students do not identify ideas and appreciation so that the students' ability to write explanatory text is low, (2) ) students have difficulty in pouring their ideas into a complete written form, (3) students are not used to telling experiences or events through writing text so they are less structured (4) lack of students' ability to appreciate the topic (5) lack of ability to develop imagination (6) the teacher has difficulty arousing student interest in learning (7) the teacher has difficulty determining the appropriate method or way to convey the material. Therefore, there is a need for renewal in classroom learning so that it can be motivated in writing a work, for example using image media. In developing learning in the classroom, all students are expected to be actively involved in activities.

Text is writing that tells of an event that is arranged in an orderly manner, giving rise to insights that can reflect the writer's interpretation. Writing skills are very important language skills for students. These skills mean a lot to students as long as they participate in educational activities in school. Many activities are closely related to writing skills that students must complete, namely making summaries, taking notes, writing minutes, writing various kinds of letters, writing research proposals, writing activity plans, to the ability to write scientific papers. Akhaidah (2002: 2) states that writing means organizing ideas systematically and expressing them explicitly. Referring to the nature of writing above, students' writing skills can tell an event or incident in everyday life. 
Teaching writing is intended so that students are able to understand and be able to communicate ideas or ideas in writing. This is important because one's writing ability is a reflection of mastery of the language used. In general, students are able to write, but they do not have a continuous expression of ideas and do not have a logical sequence using vocabulary or grammar or language rules used so that they cannot tell clearly expressed events.

Writing can give birth to thoughts or feelings (such as composing, writing letters) by writing. Writing can also be interpreted as the expression of something using written language. Something in this case can mean thoughts, feelings, and experiences, both one's own thoughts, feelings, and experiences as well as the thoughts, feelings, and experiences of others. Through the media of learning images to write complex explanation text will be more fun, and optimal student learning outcomes.

According to the author's observations in the implementation of learning in class XI SMA Private IT AL FATTAH Desa Lama still uses the lecture learning model, namely a teacher-centered learning model, while the existence of students as active and creative children is still not being paid attention to. One of the causes of learning tends to be that children become passive, teachers have not been able to develop children's characteristics, writing complex explanatory texts is a learning material that is not mastered by students. The learning atmosphere is not exciting, students are lazy to take part in learning, and the ability to write complex explanatory texts. This condition is not solely caused by the difficulty of the learning material in writing text or the low ability of students. From the results of field studies, learning to write complex explanatory tex ts that are not conducive is caused by several things: (a) teachers do not like learning language knowledge, especially writing text, (b) teachers have little or no experience in associating with literary works, especially writing text, and (c) the learning methods chosen and used by the teacher are not or not quite right. This kind of condition will have an impact on the value of text writing skills which is still low. This can be seen from the class average score for Indonesian in writing complex explanation text material. Therefore, this problem needs to be researched and resolved.

Based on the description above, it is necessary to conduct research using classroom action (PTK) to find solutions and problems. Research develops learning tools that characterize cooperative learning models as an alternative to address Indonesian language learning. Cooperative learning model or cooperative learning, cooperative learning includes a small group that works as a team to solve a problem, complete a task, or work on something to achieve the group's collective goals.

Therefore, it is necessary to have teacher creativity in order to have the expertise to choose and use appropriate learning strategies so that learning is fun and students are able to be active so that success in learning can be achieved optimally. According to Mulyasa (in Yiyin Anggarini, 2010: 2), teachers need to pay attention to several things to support students in achieving learning success, namely (1) reducing lecture methods, (2) materials must be modified and enriched, (3) using varied procedures, (4) ) creating learning situations that can develop children's abilities to work together, (5) involving students in various activities.

Based on the description above, the researcher can conclude that the learning model is an activity or activity carried out by someone to organize, organize and deliver learning material to students in order to receive, respond to, master and develop learning materials so that the learning process occurs.

Cooperative Learning is a form of learning based on constructivist ideas. Cooperative learning is a learning strategy with a number of students as members of small groups with different levels of ability. In completing group assignments, each student group member must work together and help each other understand the subject matter. The STAD model is a type of cooperative learning teaching method that emphasizes the existence of activities and interactions between students to motivate and help each other in mastering subject matter in order to achieve maximum achievement.

According to Slavin (2005: 3-4) in this case the application of cooperative learning is carried out, on the basis of theory students will find it easier to find and understand difficult concepts if they can discuss these concepts with their friends.

Some of the characteristics of cooperative learning are; (a) each member has a role, (b) there is a direct interaction relationship among students, (c) each member of the group is responsible for his learning as well as his group friends, (d) the teacher helps develop group interpersonal skills, (e) the teacher will only interact with the group when needed.

Some of the characteristics of cooperative learning are; (a) each member has a role, (b) there is a direct interaction relationship among students, (c) each member of the group is responsible for his learning as well as his 
group friends, (d) the teacher helps develop group interpersonal skills, (e) the teacher will only interact with the group when needed.

The main purpose of this teaching is that the teacher presents the subject matter as planned. Every beginning in cooperative learning type STAD always begins with class presentation, including opening, development and guided practice of the whole lesson with an emphasis in presenting the subject matter.

\section{METHODOLOGI}

The form of PTK carried out in this research is collaborative. In conducting the research, the writer as a teacher of Indonesian Language in collaboration with other parties with fellow Indonesian language subject teachers. So that during the research activity the writer is assisted by an observer who functions as an observer. This is so that other researchers can provide input or more complete data information if researchers are not careful in collecting data. The research design used refers to the Kemmis and M.C. models. Taggart (in Arikunto 2009: 16) which consists of 4 components, namely: planning, action, observation, and reflection.

The subject of this Classroom Action Research Research was carried out in Class XI SMA SWASTA IT AL FATTAH Lma Village on October 1, 2020 in the Indonesian language subject with 23 students consisting of 15 male students and 8 female students. As one of the schools located in the suburbs, only a few students in the school's daily communication use Indonesian. The level of education of parents also affects the ability of the majority of students, which is relatively low, especially in speaking Indonesian. The habit of using their mother tongue (local language), in this case Malay, causes them a little difficulty in speaking Indonesian properly.

Basically, Classroom Action Research (CAR) has the following characteristics: (1) it is situational, meaning that it tries to diagnose problems in a particular context, and tries to solve them in that context; (2) there is collaboration-participatory; (3) self-evaluative, namely modifications carried out continuously - evaluated in a situation that continues in a cycle, with the aim of an increase in actual practice. The Classroom Action Research stage generally includes four steps.

Observation techniques are used to see and observe events that occur in the field directly. This statement is in accordance with the opinion of Riduwan (2004: 104) states that the observation technique is a data collection technique, in which the researcher makes direct observations on the research object to take a close look at the activities carried out. Based on the above opinion, according to researchers the observation technique is the method used to collect data, in which the researcher makes direct observations of the research object. Meanwhile, Arikunto (2009: 19) states that the observation stage is an observation activity carried out by the observer.

Observation activities are carried out collaboratively to observe teacher skills, as well as student learning outcomes in Indonesian language learning applying the STAD mudel. Observations related to process evaluation activities and learning outcomes can be done formally, namely observation using instruments that are deliberately designed to observe student performance and learning progress, as well as informal observations that can be made by researchers without using instruments. In this study, researchers conducted observations in accordance with Hadi's opinion (in Sugiyono 2010: 145) observing a complex process composed of various observation and memory processes. This statement is in accordance with the opinion of Wiraatmadja (2006: 125) which states that field notes are a very important source of information made by researchers or research partners who make observations or observations. Based on the above opinion, according to the researcher the field notes used by the researcher contain very important sources of information made by the researcher who is making observations.

Reflection is an act of evaluating the trials that have been carried out, namely reviewing it by correcting deficiencies that exist in the learning process. At this stage the writer has done in accordance with the opinion of Arikunto (2009: 19-20) that "reflection on activities is used to restate what has been done". After assessing teacher skills, student activities and student learning outcomes, the researchers made improvements in the next cycle. The reflection activity consists of 4 activity components, namely: analysis, interpretation, explanation of the data from the analysis and concluding whether the problem is resolved or not. Researchers will see whether the predetermined performance indicators have been achieved or not. If this has not been achieved, the researcher continues the following cycle until he reaches the performance indicator. However, if the results of the data on teacher skills and learning outcomes reach the predetermined success indicators, the research is terminated.

\section{RESULT AND DISCUSSION}

The results of the observation of the STAD learning model have been implemented well and are in accordance with the steps in the learning implementation plan. teacher activities in the implementation of the action in cycle I, namely the teacher has carried out learning well, including the teacher has opened the lesson well, by giving 
first perceptions, then the teacher prepares learning media, shows students and provides material explanations about writing Complex Explanation texts. Then the teacher asks students to study the material themselves by reading the reading text that has been given by the teacher. The next activity is that the teacher forms groups of 4 groups in 1 class. Students carry out group discussions and are guided by the teacher, group discussions run smoothly because the teacher can manage the class well.

The next step is the main step, namely the teacher invites students to observe the picture before being invited to imagine the teacher first explaining how to arrange it word by word. Students seem to pay attention when the teacher explains how to arrange words. After finishing explaining the students began to compose words. Students seem to be more active in expressing opinions and students find it easier to understand the material through observations like this. Then the last step taken by the teacher is reflecting, concluding the material that has been taught, this is so that students have stability towards the material that has been taught. Teachers who teach using appropriate learning strategies will be able to generate student interest in learning, on the other hand, teachers who do not use inappropriate learning strategies will not be able to generate interest in student learning. So it can be seen from the percentage of teacher activity achieved with the average score obtained in the first cycle, which is $73 \%$. The implementation of the steps of the STAD learning model in cycle II is in accordance with the planning that has been implemented as in cycle I. Based on observations in cycle II it can be implemented optimally as well. This is evident from the results of the percentage of teacher activity with an average score obtained in the second cycle, which is $95 \%$. The increase in the percentage of teacher activity indicates that the teacher has mastered and can apply the steps of the STAD learning model well

At the time before learning activities were carried out using the STAD model, student learning outcomes could be said to be low because the success rate of students only reached 52\%, namely from 23 students only 12 students completed their studies and the average final result in the class was only 68. Cycle I, the final score of student learning showed an increase, namely the percentage of students' average completeness reached $69 \%$, which means an increase of $13 \%$. In general, this can be said to be incomplete because it has not reached $75 \%$ of its class. Therefore, the results of the improvement in cycle II showed that an average of $83 \%$ of students had finished learning. In general, this can be said to be complete because the achievement of above $75 \%$ is complete learning in class. These results indicate that the STAD learning model can be used to improve Indonesian learning outcomes in writing Complex Explanation texts.

\section{CONCLUSION}

The results of research on learning Indonesian Language Writing Complex Explanation texts through the STAD learning model in class XI IT Al Fattah Private High School, Lama Village, Hamparan Perah District, Deli Serdang Regency and the discussion presented in the discussion section can be concluded as follows: (1) Application of the STAD model in learning Indonesian Language Writing complex explanation text has been implemented properly and in accordance with the existing steps. This is evident from the results of teacher activities in teaching, namely in the first cycle the average presentation reached $73 \%$. Whereas in cycle II the teacher activity reached an average of $95 \%$. (2) Indonesian learning outcomes Writing Complex Explanation text Complex Explanation text through STAD learning model in class XI students of IT Al Fattah Private High School, Lama Village, Hamparan Perak District, Deli Serdang Regency can increase, this is indicated by an increase in the average student learning outcomes and percentage completeness achieved. The average final score obtained by students in cycle I reached $69 \%$, while in cycle II the average was $78 \%$, while the average percentage of completeness achieved in cycle I reached 59\%, in cycle II the average presentation reached $85 \%$.

Conclusions from learning Indonesian Writing complex explanatory text texts through the STAD learning model in class XI students of private high school IT AL FATTAH Desa Lama, Hamparan Perak, Deli Serdang Regency, the researchers provide suggestions, namely (1) For teachers, applying the STAD learning model as one solutions to improve the quality of Indonesian language learning writing Complex Explanation texts include teacher skills in teaching and student learning outcomes. (2) For students, be more serious in following the learning process, especially in the Indonesian language subject in writing Complex Explanation texts. by using the image media of the STAD (Student Teams Achievement Division) learning model. (3) For schools, it can be used as an input in using the learning model, especially in Indonesian subjects. (4) For further researchers, hopefully the results of this study can be used as information to conduct further research by using more complex research models and strategies in accordance with the characteristics of students and subject matter. 


\section{DAFTAR PUSTAKA}

Arikunto, Suharsimi. 2009. Classroom Action Research. Jakarta: PT. Earth Literacy.

Slavin, Robert E. 2005 Cooperative Learning Raecech. Bandung: Nusa Media

Kemmis, S and Mc. Taggart, R 1998. The Action Research Planner-Victoria Dearcin University.

Kuntjojo et al; 2011. Learning Models Module. Modules are presented in

Education and Training for Professional Teachers at PSG Sub-District of Nusantara University PGRI Kediri, Kediri, 2011

Riduwan. 2004. Research Methods. Jakarta: Rineka Cipta.

Sugiyono. 2010. Qualitative and Quantitative Research Methods R \& D. Bandung: Alfabeta.

Wiraatmadja, Rochiati. 2006. Classroom Action Research Methods. Bandung: Rosdakarya 